\title{
ARTIGO
}

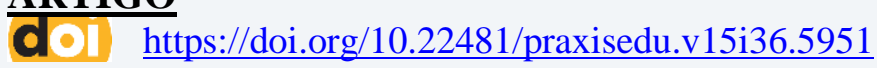

\section{THE WAYS AND MODELS OF HIGHER EDUCATION DEVELOPMENT}

\author{
LAS FORMAS Y MODELOS DE DESARROLLO DE LA EDUCACIÓN SUPERIOR
}

\section{AS FORMAS E MODELOS DE DESENVOLVIMENTO DO ENSINO SUPERIOR}

Marat R. Safiullin

Kazan Federal University - Russia

Aliya A. Shugaepova

Kazan Federal University - Russia

Dilyara I. Shakirzyanova

Kazan Federal University - Russia

Resumo: O artigo é dedicado ao estudo das características e perspectivas de desenvolvimento do sistema de ensino superior, tanto na arena global quanto na Rússia. Os resultados do estudo são baseados nas opiniões de especialistas e profissionais estrangeiros e russos da esfera da educação. As pesquisas foram divididas nos principais blocos, como as tendências no desenvolvimento do sistema de ensino superior no mundo e na Rússia; o sistema de ensino superior na Rússia e sua transformação em novas realidades econômicas e sociais; o sistema internacional de avaliação de universidades e suas perspectivas na Federação Russa; as formas de desenvolvimento das universidades russas no mundo digital moderno. São apresentadas as opiniões de especialistas sobre o conceito de modelo de referência universitário.

Palavras-chave: Ensino superior; Educação internacional; Modelo de referência da universidade, Reformas educacionais; Tendências da educação.

Abstract: The article is devoted to the study of the features and prospects of development of the system of higher education, both in the global arena and in Russia. The results of the study are based on the opinions of foreign and Russian experts and practitioners from the sphere of education. The surveys were divided into the main blocks, such as the trends in development of higher education system in the world and in Russia; the system of higher education in Russia and its transformation in new economic and social realities; the international system for the assessment of universities, and its prospects in the Russian Federation; the ways of development of Russian universities in the modern digital world. The opinions of experts on the concept of university reference model are presented. 
Keywords: Higher education; International education; Reference model of university; Education reforms; Trends in education.

Resumen: El artículo está dedicado al estudio de las características y perspectivas de desarrollo del sistema de educación superior, tanto en el ámbito mundial como en Rusia. Los resultados del estudio se basan en las opiniones de expertos y profesionales extranjeros y rusos del ámbito de la educación. Las encuestas se dividieron en los bloques principales, como las tendencias en el desarrollo del sistema de educación superior en el mundo y en Rusia; el sistema de educación superior en Rusia y su transformación en nuevas realidades económicas y sociales; el sistema internacional para la evaluación de universidades y sus perspectivas en la Federación de Rusia; Las formas de desarrollo de las universidades rusas en el mundo digital moderno. Se presentan las opiniones de expertos sobre el concepto de modelo de referencia universitaria.

Palabras clave: Educación superior; Educación internacional; Modelo de referencia de la universidad; Reformas educativas; Tendencias en educación.

\section{Introduction}

The system of higher education is a core social institution, which provides the innovative and intellectual foundation for a new technological structure. In the 2000s, there was a reforming of higher education in Russia. In the process of transformation of higher education, a new model of universities has emerged. The following questions are becoming relevant: in what direction the modern education structures should move, and what trends form the strategies for the development of educational systems. For this purpose, the research was conducted on the development of the system of higher education in Russia and abroad (Pakdel \& Talebbeydokhti, 2018; Gomez et al., 2018; Kenan, 2018; Akkuzova et al., 2018).

The issues of development of higher education were studied by various scientists. Among them, both foreign scientists and Russian researchers can be noted (Goncharenko, 2018; Shakirova et al., 2016; Altbach \& Knight, 2007; Olssen \& Peters, 2005; Rizvi \& Lingard, 2009; Romanov, 2018; Sarsenbayeva et al., 2015; Schofer \& Meyer, 2005).

\section{Methods}

This research is devoted to the development of the Russian system of higher education in the period 2010 - 2018. The article presents the results of interviews with the representatives 
of the world and Russian educational environment: international experts in the global education system, representatives of government and Project 5-100, Russian researchers and practitioners of higher education, as well as the officials and scientists of Kazan Federal University. A total of 17 respondents participated in the survey. The structure of the respondents is represented by the following ratio: $17 \%$ of international experts in the field of education, $18 \%$ of representatives of Project 5-100 and Russian authorities, 18\% of Russian experts in the field of education, $47 \%$ of senior government officials and representatives of universities.

The respondents were asked questions as the experts in the field of global and national higher education, in particular about educational development trends, reforms in the Russian system of education, as well as about the model of University of the Future. All questions in this study were open. So, the respondent was given the opportunity to freely formulate the answers and give a detailed characteristic and description of the problems. In the research, the questions were grouped into blocks: trends in the development of higher education; the system of higher education in Russia before its transformation in the 2000s; international system for the assessment of universities and its prospects in the Russian Federation; development paths of Russian universities in the modern digital world.

\section{Results And Discussion}

The main results of the study are presented below. The answers were consolidated into the following blocks: global and national trends in science and education; international systems for the assessment of universities competitiveness; transformation of the system of higher education in Russia; development paths of the universities and the model of University of the Future.

The first is the block of trends in science and education. Among the most frequent answers of respondents is the issue of changes in the conditions and ways of organization of people's lives, that undoubtedly has a direct impact on the development of the system of higher education, both in the world and in Russia. The change of the climate and living environment of the world's population and the introduction of advanced technologies lead to the new ways of organization of human existence and work. This, in turn, requires the reorientation of educational system to new demands and trends of the population. The share of such answers in the structure of the analyzed data was $17 \%$. 
An important place among the answers of experts is occupied by the information technologies of the present and future world, which have developed in the modern system of education. The shares of the answers, consolidated in the subgroups "the availability of online education, including distance learning, will take a special place in the system of competitiveness of the universities" and "the technologies of virtual reality and artificial intelligence will be introduced into training, new ways of obtaining knowledge will appear, which will need to be followed by advanced universities" in the structure of the sample were $14 \%$ and $14 \%$.

According to the opinion of the researchers and practitioners of the system of higher education, there is the globalization, the blurring of existing distinction in science and education, and the development of interdisciplinarity. The share of such answers is $14 \%$ of all responses.

Among the most popular answers of scientists, there are questions, regarding the competition of universities. According to the experts, the competition will be intensified in the near and distant future, including due to the emergence of other providers of educational services (these can be the enterprises, which organize training of their personnel, the private sector, actively developing the technologies of distance learning). This subgroup is represented by $7 \%$ of answers.

The number of answers "There will be a focus of education towards its individualization" is also amounted to $7 \%$. The experts note the importance of cultivation of human personality in accordance with individual needs and the demands of labor market.

The list of the main and frequent answers of the respondents is presented in Figure 1.
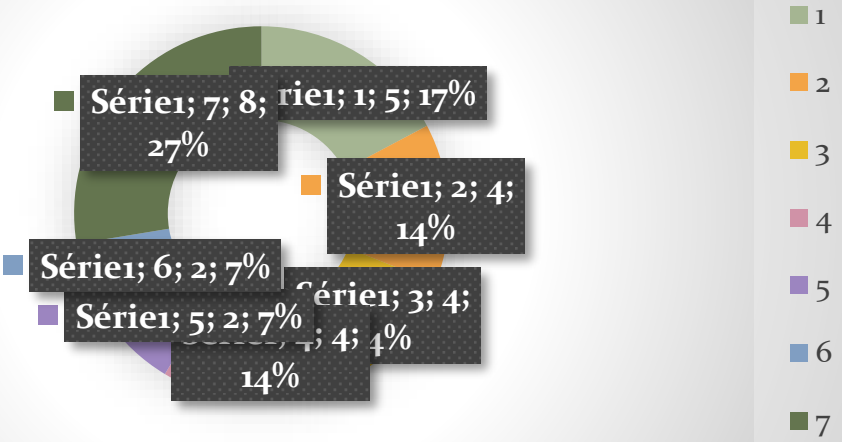

1 The very idea of a normal career, life and work of a person will change, and $(17 \%)$ the students of senior generation will appear at universities.

2 The availability of online education, including distance learning, will take a

(14\%) special place in the system of competitiveness of the universities. 
The technologies of virtual reality and artificial intelligence will be introduced into training, new ways of obtaining knowledge will appear, which will need to be followed by advanced universities.

4 There will be the globalization of science and the development of its (14\%) interdisciplinarity.

$5(7 \%)$ The competition will be tightened, including due to the emergence of other

$6(7 \%) \quad$ There will be a focus of education

7 $(27 \%)$ Other

Fig. 1. The most frequent answers. Block "trends in science and education".

Despite the fact that a significant share is occupied by the answers about the development of distance learning technologies, some experts note that the classic campus will play an important role, when there is a direct interaction between people.

As opposed to the increased competition and the emergence of new players in the educational market, the experts note that global demand will increase, in particular, due to the uprising of interest in higher education in Asian countries.

Other answers, given by respondents, are presented in table 1.

Table 1. Other answers. Block "trends in science and education".

\begin{tabular}{|c|}
\hline $\begin{array}{l}\text { Human co-operation and interaction will play an important role; the traditional university } \\
\text { campus will receive an impetus for development. }\end{array}$ \\
\hline $\begin{array}{l}\text { The brand of the educational institution will be important when choosing a university; } \\
\text { students will prefer "famous" universities. }\end{array}$ \\
\hline $\begin{array}{l}\text { There is and will be the growth in demand for higher education, especially with the } \\
\text { development of "backward" countries. }\end{array}$ \\
\hline $\begin{array}{l}\text { Radical and dynamic reorientation of specialization areas will occur, due to the } \\
\text { disappearing and creation of new professions and robotization. }\end{array}$ \\
\hline A new type of universities is emerging - commercial structures in the educational market. \\
\hline $\begin{array}{l}\text { A new generation of people will appear, stupid, due to the application of modern } \\
\text { technologies, and this will be a new challenge for the universities. }\end{array}$ \\
\hline \\
\hline
\end{tabular}

The next block of answers is the international systems for the assessment of universities' competitiveness. It is represented by the following sub-blocks: the need for the competition between national universities and global "giants" of the world system of education; 
objectivity of the existing rating assessment of the competitiveness of university. The answers of experts were different regarding the issues of the need to compete with global "giants". However, it should be noted, that most scientists and practitioners emphasize the need to have a number of advanced universities in the country, which will represent it in the global arena and compete with top range world educational institutions.

Next, let's consider the main results of the block "transformation of the system of higher education in Russia". Here are the following sub-blocks: modernization of higher education in the Russian Federation and its reasons, the results of modernization of educational system in Russia.

New economic and social realities are considered by the experts as the main reasons for the necessity to transform the country's universities. In the post-Soviet period, Russia needed a new format of education, which required funding. Moreover, the universities began to present themselves in the international arena. This required new forms of cooperation and work. Among the most common groups of answers is the following: "modernization occurred because it was necessary to pay attention to the researches and innovations, which were conducted only in the academies of sciences, but not only to the educational process at the universities". The share of such answers is $31 \%$. Thus, the experts emphasize the need for the educational component of the country to enter the innovative development path, as it is established in the strategic documents of the country's development (Figure 2).

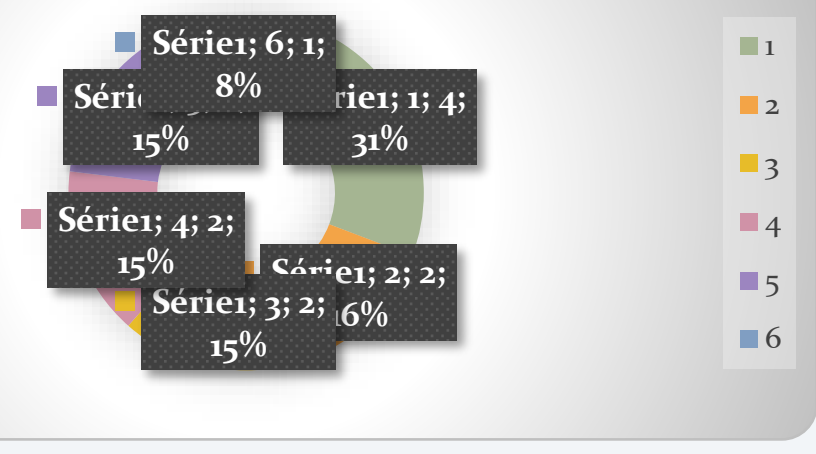

$1(31 \%)$ Modernization occurred because it was necessary to pay attention to the researches and innovations, which were conducted only in the academies of sciences, but not only to the educational process at the universities.

$2(16 \%) \quad$ Unsatisfactory reputation and positioning of our country in the system of education on the global stage.

$3(15 \%) \quad$ Modernization is a cyclical process; unification and enlargement is accompanied by disintegration and vice versa. Therefore it occurred objectively. 
$4(15 \%) \quad$ The reason for modernization was the emergence of demand from society for new programs, which were relevant to the labor market, not represented in that [past] educational system, including the outflow of minds abroad.

$5(15 \%)$ There was a stabilization of socio-economic situation in the country and the creation of a model for its development in new post-Soviet realities, including in the system of higher education.

$6(8 \%)$ Modernization has occurred due to the need to equip universities with the material, technical, information and innovative means.

Fig. 2. The most frequent answers. Sub-block "modernization of higher education in the

Russian Federation and its reasons".

According to the experts, the results of modernization of educational system in Russia are the following: due to new programs of education and science support, the universities significantly improved the level of equipment of scientific and educational process. However, some experts note that the universities are only at the beginning of the educational system transformation, and they have not yet reached the goals, set for the system of higher education in Russia (Figure 3).

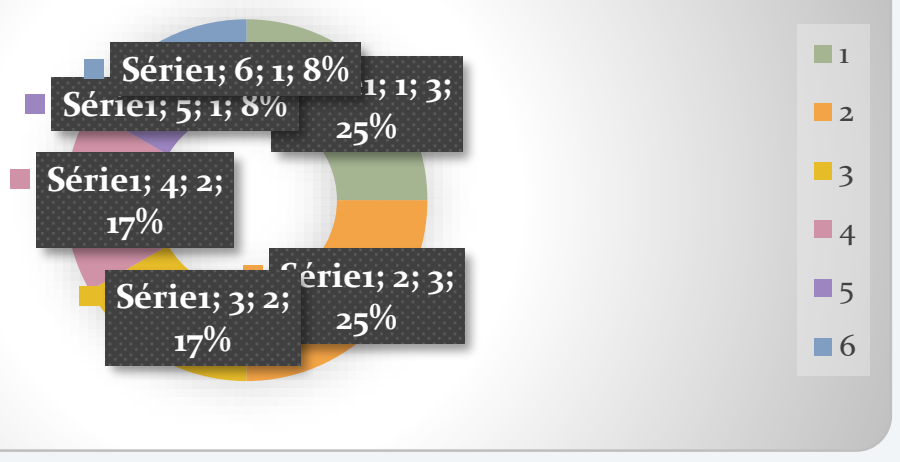

$1(25 \%)$ The universities managed to attract considerable financial resources for modernization of scientific and educational process.

$2(25 \%)$ There was a concentration of science. New breakthrough projects have been created, which are interesting for the region and the world as a whole.

$3(17 \%)$ The universities managed to focus on the issues, which weren't supported in the past (the development of youth science, the creation of own production, etc.).

$4(17 \%)$ The universities are only at the beginning of their modernization and development. They have not yet reached the goals of modernization, including research.

In general, the project of federal universities was not implemented, since

$5(8 \%)$ modernization initiatives have not yet been developed, different universities had very different starting points.

$6(8 \%)$ Internal competition has been lost, as a result of consolidation of universities.

Fig. 3. The most frequent answers. Sub-block "the results of modernization of educational system in Russia". 
The last block of the research "development paths of universities and the model of University of the Future" include the following sub-blocks: the reference model of university, the model of University of the Future; the main functions and tasks of University of the Future; prospects and recommendations for Russian universities.

The following answers were received to the questions, regarding the reference model of university and the model of University of the Future. It is worth noting that the majority of respondents are inclined to believe that universities of the future will serve the social needs of population, including the creation of happy people, who will be satisfied with their activities in new economic and social formations. So, the number of answers "the universities of the future will serve human needs; their task will be to prepare a person for a successful life, not only as a specialist, but as a conscious and satisfied individual, able to implement his own projects, in the created environment" is amounted to $20 \%$ in the total structure of responses. The experts also emphasize the innovative and entrepreneurial components of University of the Future as the important elements. So, the answer "models of the future are the research and entrepreneurial models; the university within the economy should play the role of supplier of new knowledge, useful for someone" has $16 \%$. Despite the presence of certain ideas about the model of University of the Future, a number of experts noted that there can be no standard model, since each university has its own geographical features, heritage and culture. The obtained answers are presented in Figure 4.

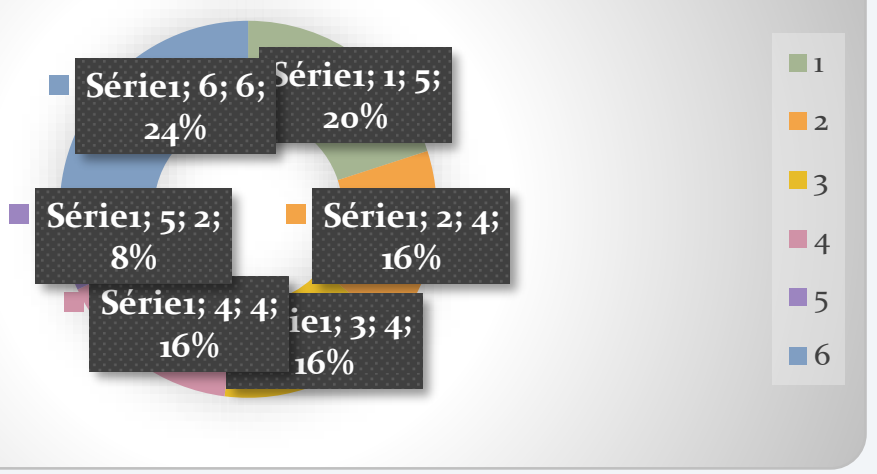

$1(20 \%)$ The universities of the future will serve human needs; their task will be to prepare a person for a successful life, not only as a specialist, but as a conscious and satisfied individual, able to implement his own projects, in the created environment.

$2(16 \%)$ The reference model of university is a combination of scientific, innovative, educational and social functions; education is based on the science; satisfied social environment is formed.

$3(16 \%)$ Models of the future are the research and entrepreneurial models; the university within the economy should play the role of supplier of new knowledge, useful for someone. 
$4(16 \%)$ There is no reference model, the true model of the university is that corresponds to its real activities.

$5(8 \%)$ University of the Future is a university with an interdisciplinary approach, where disciplines and fields of study are mixed.

$6(24 \%)$ Other

Fig. 4. The most frequent answers. Sub-block "the reference model of university, model of University of the Future".

Table 2. Other answers. Block "development paths of universities and the model of University of the Future". Sub-block "the reference model of university, the model of University of the Future".

The reference model of university is a team of high-end professionals, having the goal of innovation and entrepreneurship production.

The core of an ideal university model consists of the following elements: incoming cash flow, talents (staff and students) and prudent management (with the elements of autonomy).

University of the Future is a university, which is one step ahead, having the purpose to train the specialists of the future and to meet the upcoming challenges.

University of the Future will be the same as it is now, live communication will be a priority. Other

According to the experts, the prospects and recommendations for Russian universities can be pointed out in the following order (Figure 5). It should be noted, that above all, a number of experts emphasize the importance of creation of an attractive environment for the talents, and at the same time, without losing of their individuality, and taking into account the features of territorial development.

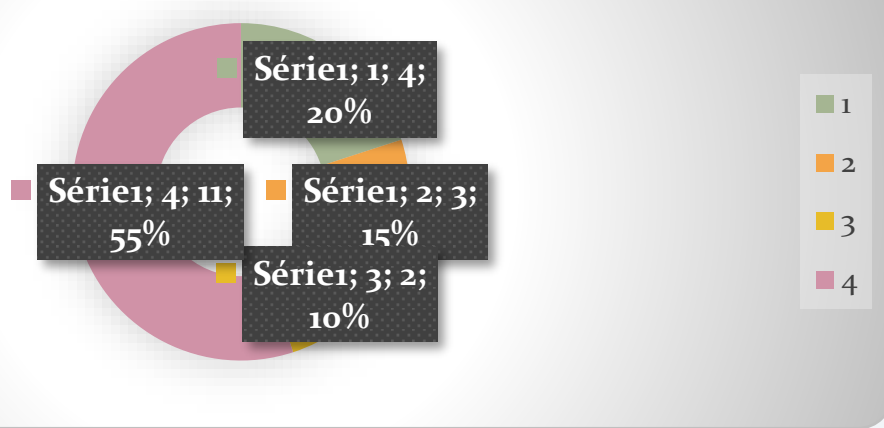

1 It is necessary to create an attractive environment (material and nonmaterial) to (20\%) attract, develop and keep the talents.

2 It is important to preserve the culture and individuality of the university.

$(15 \%)$

3 It is necessary to work with the information space, talk about the future in real time, $(10 \%)$ have multilingual sites, and work with electronic services. 
4 $(55 \%)$

Fig. 5. The most frequent answers. Sub-block "the prospects and recommendations for Russian universities".

\section{Summary}

According to the opinion of experts, the main trends in science and education are associated with the upcoming changes in the conditions, forms of existence and life of people, their requirements for information, education and science. The creation of a new generation community will entail the emergence of new forms of training, new classes of students. The universities should be ready for this, be one step ahead, create programs and apply technologies, determined by the realities of the environment. The massive introduction of tools of virtual reality, distance learning, artificial intelligence is defined by the researchers as an important trend in the evolution of higher education. Interdisciplinarity and the development of network forms of interaction are relevant for the science. The emergence of new competitors in the sphere of educational services will lead the universities to the creation of better and more attractive structure.

\section{Conclusions}

So, the following conclusions and main trends can be distinguished:

1. The countries should have several global universities; at the same time, it is advisable to establish the classification of universities and emphasize their uniqueness.

2. To be globally recognized and competitive in the world markets, the universities should present on rating sites.

3. Modernization of the system of higher education in Russia was performed with the aim to form more innovative structures, as well as to meet the newly created economic and social conditions. However, the modernization goals have not yet been achieved, with the exception of particular universities.

4. There is no reference model of University of the Future, but this university should serve society, educate people, satisfied with their lives, capable of conducting entrepreneurial activities and generating new ideas.

5. In order to become more successful in the global market, Russian universities must provide the favorable environment, which can attract and develop the talents. 


\section{Acknowledgements}

The work is performed according to the Russian Government Program of Competitive Growth of Kazan Federal University.

This work was carried out at the expense of the subsidy, allocated to Kazan State University for the fulfillment of the state task in the field of scientific activity (No. 26.9776.2017/BCh)

\section{REFERENCES}

1. Goncharenko, A. N. (2018). Current trends in the development of higher education in the conditions of continuous changes in the requirements for training of specialists. Labor and social relations, 4, 5-12.

2. Shakirova, Yu. A., Schetnikova, I. L., Garyaeva, A. F., \& Shugaepova, A. A. (2016). The analysis of the impact of internationalization factors on the rating of Russian universities. University Management: Practice and Analysis, 6, 111-119.

4. Altbach, P. G., \& Knight, J. (2007). The internationalization of higher education: Motivations and realities. Journal of studies in international education, 11(3-4), 290305.

5. Olssen*, M., \& Peters, M. A. (2005). Neoliberalism, higher education and the knowledge economy: From the free market to knowledge capitalism. Journal of education policy, 20(3), 313-345.

6. Rizvi, F., \& Lingard, B. (2009). Globalizing education policy. Routledge.

7. Romanov, E. V. (2018). Higher Education: Current State and Development Prospects [Высшее Образование: Состояние И Перспективы Развития]. Economic Policy, 3, 182-205.

8. Sarsenbayeva, G., Kozybay, A., \& Anarbek, L. (2015). Quality Assurance of Higher Education: National Trends of Development and Accreditation in Kazakhstan. European Journal of Natural History, (6), 38-40.

9. Schofer, E., \& Meyer, J. W. (2005). The worldwide expansion of higher education in the twentieth century. American sociological review, 70(6), 898-920.

10. Pakdel, M., \& Talebbeydokhti, A. (2018). The Effect of Adjustment Announcement of Predicted Profit on Price and Trading Volume of Listed Companies in Tehran Stock Exchange. Dutch Journal of Finance and Management, 2(1), 49. https://doi.org/10.29333/djfm/5825

11. Gomez, H. F., Lozada, E. F., Martínez, C. E., Baño, F. P., Álvarez, G. A., Culque, W. V., . . Cevallos, R. E. S. (2018). Introduction to the Analysis of Tourism Services 
through Feelings Mining. Journal of Information Systems Engineering \& Management, 3(4), 33.

12. Kenan, K. X. (2018). Seeing and the Ability to See: A Framework for Viewing Geometric Cube Problems. International Electronic Journal of Mathematics Education, 13(2), 57-60. https://doi.org/10.12973/iejme/2695

13. Akkuzova, A., Mankeyev, Z., Akkuzov, A., Kaiyrbekova, U., \& Baiymbetova, R. (2018). Some features of the meaning "literary text" in the pragmalinguistic aspect. Opción, 34(85-2), 20-34.

\section{SOBRE OS AUTORES:}

\section{Marat R. Safiullin}

Kazan Federal University, Russia , Tel.: +7 (843)2337769

Email: belova-t@ores.su

(iD http://orcid.org/0000-0002-3286-719X

\section{Aliya A. Shugaepova}

Kazan Federal University, Russia ,Tel.: +7 (843)2337769

Email: a.shugaepova@mail.ru

iD http://orcid.org/0000-0002-1176-0174

\section{Dilyara I. Shakirzyanova}

Kazan Federal University Russia ,Tel.: +7 (843)2337769

Email: editor@ores.su

(iD http://orcid.org/0000-0001-6760-4042

Recebido em: 27 de outubro de 2019 Aprovado em: 19 de novembro de 2019 Publicado em: 10 de dezembro de 2019 